\title{
Borrowed Time
}

Samuel M. Miller, BS

I am 14 years old, and we are having steak for dinner. We rarely eat steak in my family, but tonight is special because my father and I won the Seaview Men's Doubles Tournament earlier that day. My Grandma Lillie routinely insists that Grandpa Joe cuts his meat into smaller pieces so he doesn't choke, but I always assumed she was just being overly cautious.

I'm still chewing as I look up from my steak, startled by the rattling dishes. Across the table, my Grandpa Joe is banging his fists on the table as he has done at least once at almost every dinner we've shared-but this time, he isn't laughing. His eyes are wide and his face is red as his jaw moves back and forth in an exaggerated attempt to clear his throat. He can't.

My father, a family physician, rises from his chair and asks Joe if he needs help. Joe shakes his head, but is still unable to cough. He takes a couple sips of water but cannot swallow them; the water dribbles out of his mouth. He grasps his throat and spastically motions for my father to help him.

My father positions himself behind his father. He is giving him the Heimlich, but still, no sound. I watch as a look of desperation begins to make its way across my father's face. There is so much strength behind each thrust that Joe is being lifted off the ground. His feet slam into the hardwood floors at a steady pace, almost as if he is ticking away the seconds of his life. I can feel time slow down.

My mother yells, "Honey, should I call 911?"

"Yes, call 911," he replies.

She disappears into the kitchen as my Grandma Lillie, my brother, and I circle around my father. A terrifying thought instills itself in my head-I am watching my Grandpa die.

Joe's face has turned blue. His eyes are closed and his mouth hangs open. There is no strength left in his neck and his head leans to the right. He grabs onto the lamp next to him to try to keep his balance, but his legs are too weak. My father tries to break his fall, but there is still a loud thud as he collapses. We have not seen any signs of life for what was probably a few seconds; it feels like a whole day.

My father has turned Joe onto his back and is straddling his chest. A last couple of desperate shoves to his chest avail nothing. Joe is dead on the floor.

DOI: http://dx.doi.org/10.4300/JGME-D-16-00370.1
"Just send somebody now!" My mother is yelling into the receiver, still talking to the emergency service on the phone. "He's dying on the floor!"

My father joins her with screaming of his own. "Get me a knife," he calls. My mother, still on the phone, stretches into the dining room and hands him a bread knife. The knife is completely dull and so he yells again, this time louder, "Get me a sharp knife!"

"Get me some alcohol!" I run to grab the rubbing alcohol from the bathroom and sprint back to the dining room to find my father crouched over Joe's neck, knife in hand.

He looks as though he is petting Joe's neck. I look closer and see his hand wrapped around the wooden handle of the knife, his index finger white as he pushes on the blade. He breaks the skin and blood starts to pour from the wound. I watch my father slip 2 fingers into the incision. He finds the trachea, secures it, and picks up the knife again, bracing for his second cut.

As he maneuvers the knife he yells, "Get me a straw." No one in our family uses straws and so a couple of seconds later, he calls out again, "Bring me a pen!" I bring him the pen.

An attempt to break the pen in half fails. My father picks up the bread knife and begins to saw at the ends of the pen. He has created a makeshift straw and places it into Joe's trachea. He crouches over Joe and begins to blow.

Joe's chest rises and falls with my father's breaths. Color returns to his face. My father feels for a pulse. He finds it.

Another minute passes as Grandpa Joe continues to breathe through the pen. His eyes open and he starts to cough. The coughs become chewing motions and my father gently asks, "Do you have something in your mouth, Dad?" Joe nods, and my father follows, "Can you spit it up?" Joe nods again and, after a couple tries, opens his mouth to reveal a piece of steak, at least 2 inches long.

My chest is tight in a way I've never felt before. I am suddenly aware of my breathing again as I begin to sense that Grandpa Joe is alive. His eyes are open now, locked with my father's. He asks, in a raspy voice, "Why are you sitting on me?"

"You were choking," my father explains.

"I know, but I'm all right now. Can I get up?"

"No. You are all right, but we're going to have to take you to the hospital." 
"Well, what about dessert?" Joe asks. I know now that he is going to be all right.

Grandpa Joe lived for another 8 years. He and my Grandma Lillie got to celebrate their 65 th wedding anniversary. He was there when my brother graduated from high school, and I got to hold his hand as he passed away, peacefully and in his home, surrounded by his family. Nothing in the world can replace that time.

As I get ready to leave behind the comforts of the classroom and enter the world of clinical medicine as a third-year medical student, I am conscious that there is uncertainty that awaits me. I have heard many physicians say that medicine is not what it used to be, that the paperwork will consume me, and that physicians are being asked to do more in less time, that electronic health records and insurance companies have stripped us of the unique connection that once existed between physician and patient. I have a sense that I am about to step into a new and evolving system where I might struggle to stay out of the way, let alone be helpful. I imagine that my patience and my confidence will be tested and that at times, I will question the decisions that brought me into medicine. In these moments, I hope I remember those 8 extra years that my father was able to give us with Grandpa Joe. Maybe my miracle has already happened. Still, I hope that one day I can be a part of someone else's.

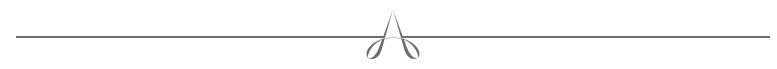

Samuel M. Miller, BS, is a Third-Year Medical Student, The Warren Alpert Medical School, Brown University.

Corresponding author: Samuel M. Miller, BS, Brown University, Box G-9284, 222 Richmond Street, Providence, RI 02912,

samuel_miller@brown.edu 